\title{
A Survey of Self-Perceived Knowledge and Knowledge Gaps of Medicines Research and Development Among Finnish General Public
}

\author{
Mirjami Tran Minh ( $\square$ mirjami.tran@helsinki.fi ) \\ Helsingin Yliopisto https://orcid.org/0000-0002-7996-7024 \\ Manu Tamminen \\ Turun Yliopisto \\ Jenni Tamminen-Sirkiä \\ Colores - Finnish Colorectal Cancer Association \\ Muntasir Mamun Majumder \\ Institute for Molecular Medicine Finland \\ Rubina Tabassum \\ Institute for Molecular Medicine Finland \\ Tuuli Lahti \\ Helsingin Yliopisto
}

\section{Research article}

Keywords: Health literacy, Medicines Research and Development, Health technology assessment, Patient and public involvement

Posted Date: July 8th, 2020

DOI: https://doi.org/10.21203/rs.3.rs-32597/v1

License: (c) (i) This work is licensed under a Creative Commons Attribution 4.0 International License. Read Full License 


\section{Abstract}

Background: This study explored self-reported knowledge and willingness to learn more about medicines research, development and health technology assessment among Finnish general public. It also aimed to define possible knowledge gaps and needs for public education regarding medicines research, development as well as health technology assessment.

This questionnaire was originally developed as a part of the Needs Assessment Work Package of the European Patients' Academy on Therapeutic Innovation (EUPATI) Project. The questionnaire was translated from English to Finnish and the survey was carried out in Finland in 2019.

Methods: The survey was conducted as an online survey by Kantar TNS Gallup Forum online panel. The data was analyzed by using the freely available $\mathrm{R}$ program. Relationships between the demographic characteristics (such as age, gender and education level) of respondents and their knowledge or interest in medicines research and development were determined using Pearson's chi-squared tests.

Results: Of the 503 respondents (age 16-64) only $12 \%$ reported having good or very good knowledge of medicines research and development in general. Regarding health technology assessment, pharmacoeconomics and regulation, the percentage of respondents reporting good or very good knowledge was as low as $8 \%$.

Respondents were most interested in learning more about predictive and personalised medicine (47 \%) and least interested in medicines regulation (30\%) and pharmacoeconomics (31\%). Those who had participated in a clinical trial had better knowledge and were significantly more interested in learning more about several aspects of medicines research, development and health technology assessment.

Conclusions: Self-reported knowledge about medicines research and development and health technology assessment appears to be very low in Finland. Patient and public participation is recognized as an important and essential element in up-to-date medical research and assessment of new treatments. In order to participate as an active and equal partner in these processes, the public needs more information and education in these topics.

\section{Trial registration}

Not applicable

\section{Background}

Participation of patients and the general public in medicines research and development (R\&D) and health technology assessment (HTA) can produce a wide range of benefits. For example, by helping the researchers to understand the needs and priorities of the patients, it yields more relevant outcome measures and better treatment adherence and may also increase both public trust and interest towards medicines R\&D (1-6).

As authorities, research groups and research funders are increasingly understanding the importance of patient and public involvement (PPI), it is gradually becoming an integral part of both medicines R\&D and HTA processes (2, 710). So far in Finland the public participation into medicines R\&D and HTA has been rather minimal and only recently, academic research groups and national HTA bodies such as the Pharmaceuticals Pricing Board and Council for Choices in Health Care in Finland have started to open some of their processes for PPI (10-13). However, the implementation of PPI in medicines R\&D and HTA requires that the public has sufficient knowledge of its concepts, methods, benefits and rationale as well as its challenges. The aim of this research was to study the self-reported 
knowledge of the Finnish public on both medicines R\&D and HTA and to define the possible knowledge gaps and needs for public education.

This survey was first conducted in six European countries as a part of the Needs Assessment Work Package of the European Patients' Academy on Therapeutic Innovation (EUPATI) Project and its results were published in 2015 (14). The survey was translated from English to Finnish and replicated in Finland in 2019.

\section{Methods}

\section{Questionnaire}

The original survey questionnaire was translated from English into Finnish by using the back-translation method and piloted with four Finnish speaking volunteers before conducting the survey in January 2019 (14).

The survey was conducted by Kantar TNS Gallup Forum online panel, which consists of recruited adults aged 15-80 who have given their explicit permission to be contacted about surveys. Panelists are recruited mainly using telephone recruitment and the panel recruitment is constant to ensure that samples drawn from it are representative of the demographics. The total size of the panel is about 40000 persons. Panelists are invited by email to answer the surveys. In this survey, we only included participants aged 16-64 years.

Participants were invited to answer this survey using a quota sampling approach, with quotas being set based on national census data on age, education and geographic region. Overall internet-penetration is fairly high in Finland (97\%). Therefore, using a panel gives a good chance to reach a sound representative sample of the target group.

\section{Statistical analyses}

The statistical analyses and data visualisation were performed on $\mathrm{R}$ version 3.6.0 (15). The relationships between the demographic characteristics (age, gender, education, participation in a clinical trial) of respondents and knowledge or interest in medical research were determined using Pearson's chi-squared tests. Statistically significant responses were determined by logistic regression. The distribution of the responses was visualised using ggplot2 version 3.3.0 (16). The data and the analysis code are available at https://github.com/manutamminen/knowledge_and_knowledge_gaps_of_medicines_research_among_finnish_public.

\section{Results}

\section{Demographic factors}

Altogether 503 respondents (age 16-64) completed the survey. Their demographic information is presented in Table 1.

Table 1. Demographic characteristics of survey respondents 


\begin{tabular}{|c|c|c|}
\hline & & Base $=503$ \\
\hline & & $\%(n)$ \\
\hline \multirow[t]{2}{*}{ Gender } & Female & $53 \%(266)$ \\
\hline & Male & $47 \%(237)$ \\
\hline \multirow[t]{5}{*}{ Age group (years) } & $16-24$ & $13 \%(67)$ \\
\hline & $25-34$ & $17 \%(86)$ \\
\hline & $35-44$ & $16 \%(78)$ \\
\hline & $45-54$ & $25 \%(123)$ \\
\hline & $55-64$ & $30 \%(149)$ \\
\hline \multirow[t]{5}{*}{ Education* } & Vocational education and training & $22 \%(112)$ \\
\hline & High school degree & $11 \%(55)$ \\
\hline & Post-secondary education & $18 \%(90)$ \\
\hline & University of Applied Science, Bachelor's degree & $21 \%(106)$ \\
\hline & University degree & $15 \%(75)$ \\
\hline \multirow[t]{2}{*}{ Experience of medical research** } & Yes & $16 \%(81)$ \\
\hline & No & $82 \%(412)$ \\
\hline \multicolumn{3}{|c|}{ *13 \% participants did not indicate their education level } \\
\hline
\end{tabular}

\section{Involvement in medical research}

$16 \%$ of the respondents had participated in a clinical trial and this was significantly more common among males (20 $\%)$ than females (13\%), $p<0.05$.

\section{Current knowledge of medicines R\&D and HTA}

Nearly $90 \%$ of the respondents reported no or poor knowledge of medicines R\&D in general. There were no significant differences between genders, age groups or education level, even though the self-reported knowledge of medicines R\&D in general appeared to decrease by respondents age (Table 2). Respondents who had participated in a clinical trial reported significantly better knowledge ( $25 \%$ reported having good or very good knowledge) than those who had not been involved in clinical trials (Table 2).

For the respondents, the most familiar topics in medicines R\&D were medicines safety (good or very good knowledge $13 \%)$, medicines development (11\%) and predictive medicine $(11 \%)$.

Regarding HTA, pharmacoeconomics and medicines regulation, only $8 \%$ of the respondents reported good or very good knowledge (Figure 1). Good or very good knowledge regarding patients' roles and responsibilities in medicines R\&D was even lower being $7 \%$. 


\section{Willingness to learn more}

Respondents were most interested in learning more about predictive and personalised medicine (47\%), and least interested in medicines regulation (30\%), pharmacoeconomics (31\%) and HTA (35\%). Females were significantly more interested in learning more about medicines safety, predictive and personalised medicine, HTA, and regulation than males ( $p<0.05$; logistic regression).

Respondents who had previously been involved in a clinical trial reported significantly better knowledge $(p<0.05$; logistic regression) in most areas of medicines R\&D and HTA and were more interested in learning more about pharmacoeconomics and medicines regulation than other respondents (Figure 1).

\section{Table 2. Current general knowledge about medicines R\&D}

\begin{tabular}{|c|c|c|c|}
\hline & & $\begin{array}{l}\text { Respondents with good or very } \\
\text { good knowledge }\end{array}$ & $\begin{array}{l}\mathrm{p} \text {-value } \\
\left(\mathbb{\Xi}^{2} \text {-test }\right)\end{array}$ \\
\hline & All participants & $12 \%(45, \mathrm{n}=389)$ & \\
\hline \multirow[t]{2}{*}{ Gender } & Female & $10 \%(20)$ & \multirow[t]{2}{*}{0.3438} \\
\hline & Male & $13 \%(25)$ & \\
\hline \multirow{2}{*}{$\begin{array}{l}\text { Earlier participation in a } \\
\text { clinical trial }\end{array}$} & Participated in a clinical trial & $25 \%(15)$ & \multirow[t]{2}{*}{0.0011} \\
\hline & Not participated in a clinical trial & $9 \%(30)$ & \\
\hline \multirow[t]{5}{*}{ Age (years) } & $16-24$ & $21 \%(10)$ & \multirow[t]{5}{*}{0.231} \\
\hline & $25-34$ & $12 \%(8)$ & \\
\hline & $35-44$ & $12 \%(7)$ & \\
\hline & $45-54$ & $11 \%(10)$ & \\
\hline & $55-64$ & $8 \%(10)$ & \\
\hline \multirow[t]{5}{*}{ Education } & $\begin{array}{l}\text { Vocational education and } \\
\text { training }\end{array}$ & $13 \%(10)$ & \multirow[t]{4}{*}{0.151} \\
\hline & High school degree & $13 \%(4)$ & \\
\hline & Post-secondary education & $9 \%(7)$ & \\
\hline & $\begin{array}{l}\text { University of Applied Science, } \\
\text { Bachelor's degree }\end{array}$ & $19 \%(17)$ & \\
\hline & University degree & $7 \%(4)$ & \\
\hline
\end{tabular}

\section{Sources of information}

Most respondents (75\%) reported using websites to find out information about medicines R\&D and HTA, and $58 \%$ reported doctors and other health care professionals to be their main source of information. Nearly a third of the respondents listed TV programs and newspapers as one source of information. 
A majority, $70 \%$ of the respondents wished to receive information about medical issues from a doctor or other health care professional, and $44 \%$ from authorities. The least popular sources of information were friends or relatives (12 $\%)$, public-private partnerships (18\%) and pharmaceutical companies (19\%).

\section{Discussion}

According to our results, Finns estimate their knowledge on medicines R\&D lower than British, French, German, Italian and Polish respondents (14). This is rather surprising as traditionally Finns have expressed strong interest towards science and research $(17,18,19)$ and as health literacy is also a part of the national school curricula in Finland (20). On the other hand, so far improvement of health literacy in general has not been included into national policy programs in Finland, although this may be partly due to differences in terms and concepts (21).

As an earlier involvement in clinical research increased patients self-reported knowledge and willingness to learn more about certain aspects of medicines R\&D and HTA, our results imply that participation into a clinical research has been an educating and perhaps also an empowering experience for the participants (14).

Respondents of this study were most interested to learn about personalised and preventive medicine - contents essential in both Finnish Health Sector Growth Strategy for Research and Innovation Activities and in Finland's Genome Strategy $(22,23)$. As the Finnish Government has recently decided to support the Health Sector Growth Strategy in 2021-2022 with an additional funding (24), these topics have also been discussed in the mainstream media, perhaps partly explaining the public interest towards them. Currently Finland is implementing several publicprivate research projects on personalised and predictive medicine, such as FinnGen, which aims at improving human health through genetic research and iCAN Digital Precision Cancer Medicine Flagship, which integrates precision medicine and digital health data for development of personalised cancer treatments $(25,26)$. Despite this, the selfreported knowledge regarding preventive medicine and genomics are rather low among Finnish public (27) and hence the importance of increasing the capacity of healthcare professionals to apply genome-based information as well as the empowerment of the public in improving their own health by effective use of genomic information is being emphasized for example in Finland's current Genome Strategy (23).

Pharmacoeconomics and HTA were the least interesting topics for respondents in this survey. One explanation for this might be that the Finnish HTA system is extremely fragmented and there is an ongoing discussion and several recommendations to simplify the system $(28,29)$. The Finnish Medicines Agency Fimea has published a recommendation to integrate patient perspectives into HTA process of pharmaceuticals $(7,30)$. However, this plan has not been fully realized yet. Currently patient organisations and the general public can only leave their comments on recommendation drafts prepared by the Council for Choices in Health Care, and provide some input for the Pharmaceuticals Pricing Board when they are assessing reimbursement statuses and wholesale prices of medicinal products $(11,12)$.

\section{Preferred sources of information}

In Finland, the public trust in health care services has traditionally been strong $(31,32)$ and our findings also indicate Finns to prefer health care professionals and authorities as the main source for health-related information. To maintain this, the knowledge-level of health care professionals needs to be kept up-to-date by organizing continuous education for them and also by allocating time and other resources of health care settings so that these complex topics can be carefully explained and discussed with patients and their caregivers $(23,33,34)$.

\section{Limitations of the study}


Generalization of these results should be done with caution as the results are based on self-reported data, which might be subjected to biases such as misunderstanding of the questions asked and biases in one's memory.

\section{Conclusions}

This study indicated a need for medicines R\&D and HTA related health literacy programs targeted for the Finnish general public. These programs could not only improve the level of public knowledge on medicines R\&D and HTA, but also empower and increase the public interest to be involved in these processes in the future, as a potential consequence of critical health literacy (35). Just recently some advancements have been made to better inform the Finnish general public on medicines R\&D and HTA as Finnish biobanks have added public information of their research and services on their websites and started to organize educational events targeting the general public (36, 37). Also, the Ministry of Social Affairs and Health has opened informative websites such as websites for the national Genome and Neuro Centers $(38,39)$ and the Finnish Medicines Agency Fimea set up a Patient Advisory Board which started to operate on spring 2020 (40). In addition, a national platform of European Patients' Academy on Therapeutic Innovation (EUPATI) was launched in Finland in 2018 providing patients and patient organizations with education on medicines R\&D as well as HTA (41). These are important advances for educating the public on medicines use. However, if authorities, companies and researchers genuinely want to involve patients and the public in medicines R\&D and integrate their contribution also in the HTA processes, there is a need to develop clear guidelines for public participation as well as increase public education on these issues. Transparent and public discussion of health care decision making and priority setting is also urgently needed (42) as new treatments are increasingly costly needing a thorough pharmacoeconomic and ethical assessment before they reach patients.

\section{List Of Abbreviations}

HTA: Health technology assessment

Medicines R\&D: Medicines research and development

\section{Declarations}

\section{Ethics approval and consent to participate}

The study participants were recruited through the Kantar TNS Gallup Forum online panel. The Kantar TNS Gallup Forum online panel consists of recruited adults aged 15-80 who have given their explicit permission to be contacted about surveys. However, this survey was only targeted to participants aged 16-64 years.

The research was carried out following the ethical principles of research with human participants of the Finnish National Board on Research Integrity TENK (43). The research was conducted respecting the dignity and autonomy of human research participants, and the research complies with the guidelines on responsible conduct of research (RCR) drawn up by TENK (44). The participants were informed about the study by an electronic letter of consent, which they had to accept before entering the online survey. The researchers had no access to any personal data of the participants.

\section{Consent for publication}

Not applicable 
Availability of data and materials

The dataset(s) supporting the conclusions of this article is available in the GitHub repository: https://github.com/manutamminen/knowledge_and_knowledge_gaps_of_medicines_research_among_finnish_public.

\section{Competing interests}

Tran Minh, Lahti, Tamminen-Sirkiä and Majumder are members of the EUPATI Finland executive committee.

\section{Funding:}

The survey was funded by the Funding Centre for Social Welfare and Health Organisations (STEA).

\section{Authors' contributions}

MTM, TL, JTS and MMM participated in planning and developing the survey. MT and RB conducted the statistical analyses. MTM, MT and TL drafted the manuscript. All authors read and approved the final version of the manuscript.

\section{Acknowledgements}

We wish to acknowledge the other members of the EUPATI Finland executive committee and Minna Anttonen for their support in conducting the research.

\section{Authors' information (optional)}

Not applicable

\section{References}

1. Health Research Authority / INVOLVE (2016), Impact of public involvement on ethical aspects of research. https://www.invo.org.uk/posttypepublication/impact-of-public-involvement-on-the-ethical-aspects-of-research/. Accessed 12 April 2020.

2. Health Technology Assessment International (HTAi). Values and Standards for Patient Involvement in HTA. https://htai.org/interest-groups/pcig/values-and-standards/ (2014). Accessed 12 April 2020.

3. Brett J, Staniszewska S, Mockford C, Herron-Marx S, Hughes J, Tysall, C. et al. Mapping the impact of patient and public involvement on health and social care research: a systematic review. Health Expect, 17: 637-650. DOI: 10.1111/j.1369-7625.2012.00795.x

4. Brett J, Staniszewska S. Mockford C. Herron-Marx S, Hughes J, Tysall, C. et al. A Systematic Review of the Impact of Patient and Public Involvement on Service Users, Researchers and Communities. Patient 7, 387-395 (2014). DOI: 10.1007/s40271-014-0065-0

5. Domecq JP, Prutsky G, Elraiyah T, Wang Z, Nabhan M, Shippee N et al. Patient engagement in research: a systematic review. BMC Health Serv Res 14, 89 (2014). DOI: 10.1186/1472-6963-14-89

6. Facey KM, Ploug Hansen H, Single A (Eds.). Patient Involvement in Health Technology Assessment. Singapore: Springer Nature Singapore Pte Ltd. 2017. DOI: 10.1007/978-981-10-4068-9 
7. Finnish Medicines Agency (Fimea). Fimean suositus potilasnäkökulman huomioimisesta haastattelututkimuksella lääkkeiden hoidollisen ja taloudellisen arvon arvioinnissa sekä siihen liittyvässä lääkeinformaatiossa. Fimea kehittää, arvioi ja informoi -julkaisusarja 3/2012. (Fimea's recommendation for integrating the patient perspective through interview study with the assessment of the therapeutic and economic value of pharmaceuticals and corresponding medicines information. Abstract in English.) http://urn.fi/URN:ISBN: 978-952-5624-24-3. Accessed 13 April 2020.

8. Let the patient revolution begin. BMJ 2013;346:f2614. DOI: https://doi.org/10.1136/bmj.f2614

9. HTA-opas. Versio 1.1. Helsinki: Suomalainen Lääkäriseura Duodecim. https://www.kaypahoito.fi/kaypahoito/menetelmat/hta-opas (2017). Accessed 12 April 2020.

10. The European Commission's Scientific Panel for Health (SPH). Better Research for Better Health. A vision for health and biomedical research from the Scientific Panel for Health. https://ec.europa.eu/programmes/horizon2020/sites/horizon2020/files/SPH_VisionPaper_02062016.pdf (2016). Accessed 12 Apri 2020.

11. Pharmaceuticals Pricing Board: Call for Patient Association (in Finnish): https://www.hila.fi/hakeminen-jailmoitukset/potilasjarjestojen-kuuleminen/ Accessed 12 April 2020.

12. Council for Choices in Health Care in Finland. https://palveluvalikoima.fi/en/ Accessed 12 April 2020.

13. Jones $\mathrm{M}$, Pietilä I. "The citizen is stepping into a new role"-Policy interpretations of patient and public involvement in Finland. Health Soc Care Community. 2017;1-8. DOI: 10.1111/hsc.12520.

14. Parsons S, Starling B, Mullan-Jensen C, Tham SG, Warner K, Wever. What the public knows and wants to know about medicines research and development: A survey of the general public in six European countries. BMJ Open, 5(4). DOI: 10.1136/bmjopen-2014-006420

15. R Core Team 2019. R: A language and environment for statistical computing. R Foundation for Statistical Computing, Vienna, Austria. https://www.R-project.org/. Accessed 6 May 2020.

16. Wickham H. ggplot2: Elegant Graphics for Data Analysis. Springer-Verlag New York, 2016.

17. European Commission. Special Eurobarometer 419. Public Perceptions of Science, Research and Innovation (2014). DOI: 10.2777/95599

18. Tieteen Tiedotus ry. Summary of the Finnish Science Barometer. A Study of the Finn's Attitudes Towards Science and Their Opinion on Scientific and Technological Progress (2016).

tieteentiedotus.fi/files/Sciencebarometer_2016_web.pdf Accessed 12 April 2020.

19. Hemminki E, Tupasela A, Jallinoja P, Aro AR, Snell K, Sihvo S. Finnish people's attitudes towards biomedical research and its sponsorship. Genomics, Society and Policy 2009, Vol.5, No.2, pp.67-79. DOI: 1186/1746-5354-5$2-67$

20. Paakkari O, Paakkari L. Health literacy and the school curriculum: The example of Finland. In: Okan O, Bauer U, Levin-Zamir D, Pinheiro P, Sørensen K. International Handbook of Health Literacy. Research, practice and policy across the lifespan. Great Britain, Policy Press; 2019. p.521-534. 
21. van der Heide I, Heijmans M, Rademakers J. Health literacy policies: European perspectives. In: Okan O, Bauer U, Levin-Zamir D, Pinheiro P, Sørensen K. International Handbook of Health Literacy. Research, practice and policy across the lifespan. Great Britain, Policy Press; 2019. p. 403-418.

22. Ministry of Employment and Economy. Health Sector Growth Strategy for Research and Innovation Activities. Roadmap for 2016-2018. MEE guidelines and other publications 8/2016. http://urn.fi/URN:ISBN:978-952-327142-5 Accessed 15 March 2020.

23. Ministry for Social Affairs and Health Care. Improving health through the use of genomic data. Finland's Genome Strategy. Working Group Proposal. Reports and memorandums of the Ministry of Social Affairs and Health 2015:34. http://urn.fi/URN:ISBN:978-952-00-3598-3 Accessed 15 March 2020.

24. Ministry of Social Affairs and Health. Decisions of the government session on spending limits will improve health and social services and pharmaceutical services. Press release 87/2020 8.4.2020 Published in English on 9.4.2020.

25. FinnGen Research Project (2020). https://www.finngen.fi/en Accessed 12 April 2020.

26. iCAN Digital Precision Cancer Medicine Flagship (2019). https://www.digitalprecisioncancermedicine.fi/ Accessed 10 March 2020.

27. Haukkala A, Vornanen $M$, Halmesvaara O, Konttinen $H$, Perola $M$, Kääriäinen H, Jallinoja, Aktan-Collan K. Suomalaisten geenitietämys ja suhtautuminen perimästä saatavaan terveystietoon. (Genetic knowledge and attitudes towards health-related genetic information among Finns). Lääketieteellinen Aikakauskirja Duodecim 2018;134(11):1187-95. https://www.terveysportti.fi/xmedia/duo/duo14350.pdf

28. Ministry for Social Affairs and Health. Näkökulmia lääkehoitoon ja lääkkeiden jakeluun liittyvistä muutostarpeista. Sosiaali- ja terveysministeriön raportteja ja muistioita 2019:5. (Points of views on Need for Changes in Medication and Distribution system of Medicines Memorandum, abstract in English). http://urn.fi/URN:ISBN:978-952-00-4027-7 Accessed 13 April 2020.

29. Ruskoaho H. Lääkekorvausjärjestelmän kehittäminen. Selvityshenkilön loppuraportti. Sosiaali-ja terveysministeriön raportteja ja muistioita 20/2018. (Development of the medicine reimbursement scheme Examiner's final report, abstract in English). http://urn.fi/URN:ISBN:978-952-00-3933-2 Accessed 13 April 2020.

30. Kleme J, Pohjanoksa-Mäntylä M, Airaksinen M, Enlund H, Kastarinen H, Peura P et al. Patient Perspective in Health Technology Assessment of Pharmaceuticals in Finland. Int J Technol Assess Health Care. 2014 Jul;30(3):306-11. DOI: 10.1017/S0266462314000282.

31. Aalto AM, Manderbacka K, Muuri A, Karvonen S, Junnila M, Pekurinen M. Mitä väestö ajattelee sosiaali- ja terveyspalveluiden uudistamisesta? Tutkimuksesta tiiviisti 4, maaliskuu 2016. Terveyden ja hyvinvoinnin laitos, Helsinki. http://urn.fi/URN:ISBN:978-952-302-635-3. Accessed 13 April 2020.

32. Parikka S, Pentala-Nikulainen O, Koskela T, Kilpeläinen H, Ikonen J, Aalto AM et al. Kansallisen terveys-, hyvinvointi ja palvelututkimus FinSoten perustulokset 2017-2018. (The FinSote National survey of health, wellbeing and service use). thl.fi/finsote. Accessed 13 April 2020

33. Ministry for Social Affairs and Health Care. National Genome Centre. https://stm.fi/en/genome-center. Accessed 13 April 2020.

Page $10 / 12$ 
34. Ministry for Social Affairs and Health Care. Hallituksen esitys eduskunnalle genomilaiksi. STM071:00/2018. (Government Proposal, Genome Act). Accessed 13 April 2020.

35. Sykes S, Wills J, Rowlands G, Popple K. Understanding critical health literacy: a concept analysis. BMC Public Health. 2013 Feb 18;13:150. DOI: 10.1186/1471-2458-13-150.

36. Finnish Biobanks. https://www.biopankki.fi/en/. Accessed 13 April 2020.

37. Helsinki Biobank. https://www.helsinginbiopankki.fi/. Accessed 13 April 2020.

38. National Genome Center. http://www.genomikeskus.fi/en/. Accessed 13 April 2020.

39. Neurocenter Finland. https://neurocenterfinland.fi/en/. Accessed 13 April 2020.

40. Finnish Medicines Agency (Fimea). The composition of Fimea's patient advisory board for the term 2020-2021 has been confirmed. News 18.11.2019. fimea.fi/web/en/-/the-composition-of-fimea-s-patient-advisory-board-forthe-term-2020-2021-has-been-confirmed. Accessed 14 April 2020.

41. EUPATI Finland. https://fi.eupati.eu. Accessed 13 April 2020.

42. Kimmel KM. Challenges in regulating priority setting in healthcare: A Finnish perspective on the lawmaker's dilemma. Medical Law International 2019, Vol. 19(2-3) 136-158. DOI: 10.1177/0968533219881177.

43. Finnish National Board on Research Integrity TENK. The ethical principles of research with human participants and ethical review in the human sciences in Finland. Finnish National Board on Research Integrity TENK guidelines 2019. https://www.tenk.fi/sites/tenk.fi/files/lhmistieteiden_eettisen_ennakkoarvioinnin_ohje_2019.pdf Accessed 15 May 2020.

44. Finnish National Board on Research Integrity TENK. Responsible conduct of research and procedures for handling allegations of misconduct in Finland. Guidelines of the Finnish Advisory Board on Research Integrity 2012. https://www.tenk.fi/sites/tenk.fi/files/HTK_ohje_2012.pdf Accessed 17 June 2020.

\section{Figures}



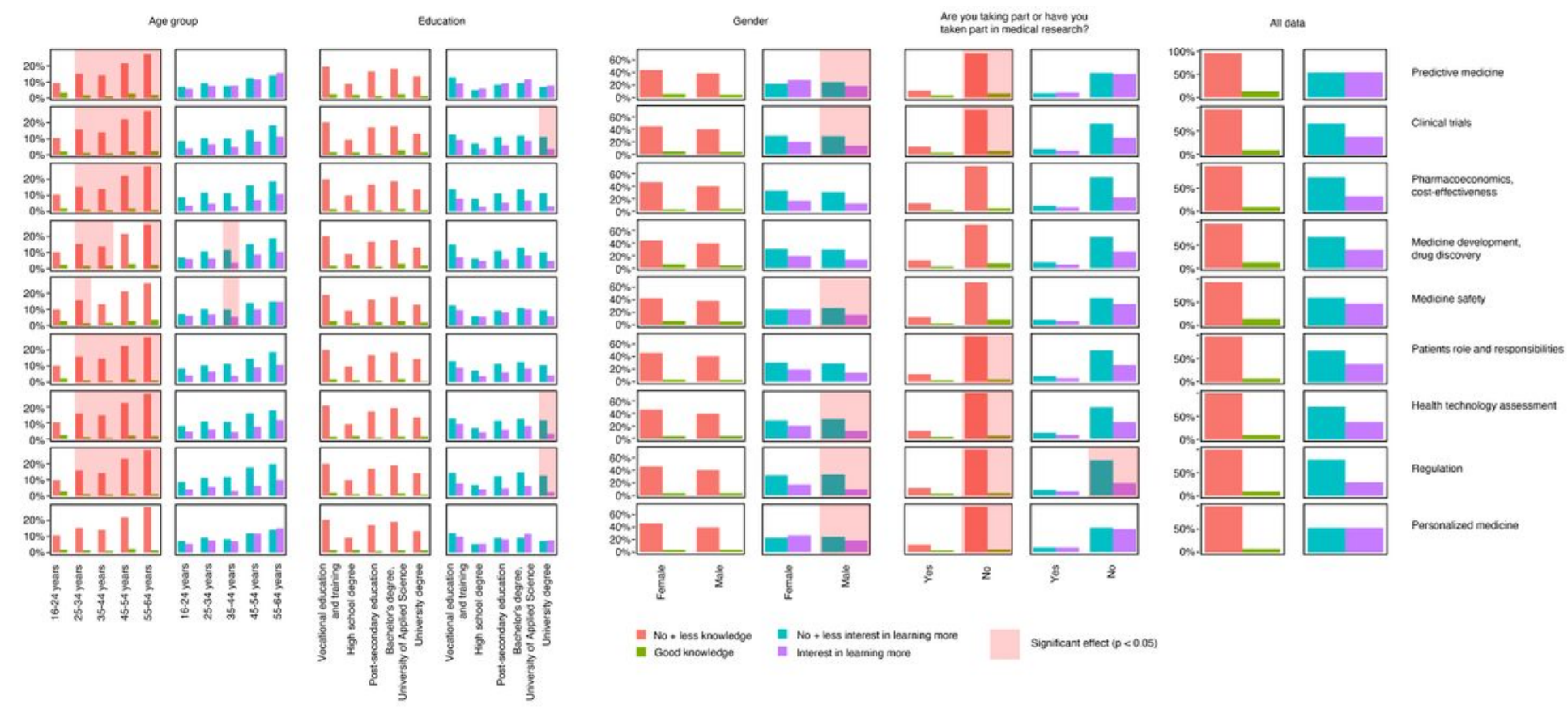

Figure 1

Distribution of current knowledge and interest in learning more about specific aspects of medicines R\&D and HTA by age, education, gender and earlier participation in clinical trials. Percentages of responses $(n=503)$ are presented in $Y$ axis and responses in $\mathrm{X}$-axis. Statistically significant responses (logistic regression; $\mathrm{p}<0.05$ ) are indicated with red shading. 